\title{
Evaluation the Application Status of GAAP in Financial Reporting Practice: In Case of Banking Sector in Bangladesh
}

\author{
Mst. Hasna Banu ${ }^{*}$, Md. Sayaduzzaman², Subhash Chandra Sil ${ }^{3}$
}

${ }^{1}$ Assistant Professor, Department of Accounting and Information Systems (AIS), University of Rajshahi, Rajshahi-6205, BANGLADESH

2Professor, Department of Accounting and Information Systems (AIS), University of Rajshahi, Rajshahi-6205, BANGLADESH

${ }^{3}$ Professor, Department of Accounting and Information Systems (AIS), University of Rajshahi, Rajshahi-6205, BANGLADESH

*E-mail for correspondence: hasna@ru.ac.bd

https://doi.org/10.18034/abr.v11i2.577

\begin{abstract}
The prime concentration of this study is to scan the respondents' opinions regarding the application status of the different units of GAAP in preparing the different financial reports by the sample banks. To meet this objective an attempt has been made to collect opinions from one hundred fifty respondents comprising of fifty chartered accountants, fifty cost and management accountants as well as fifty academicians. Frequency analysis has been used to evaluate their perceptions. The result of frequency analysis reveals that the sample banks greatly apply the accounting entity assumption, going concern assumption, assumption of a stable momentary unit as well as time period assumption in preparing the financial statements. Furthermore, this study has likewise employed ANOVA as well as Chi-square techniques to investigate whether there is any significant deviation amidst the respondents' opinion concerning the execution of different segments of GAAP for financial reporting practice of the sample banks and the outcomes indicate that there is the significant difference among the respondents' opinion regarding the application status of the different units of GAAP in financial reporting practice by the sample banks in some cases and in other cases the difference of opinion has also been observed.
\end{abstract}

Key words: Financial Statements, GAAP, State-Owned Commercial Banks, Bangladesh

\section{INTRODUCTION}

Banks have a great influences in the economic advancement of any country and they collect fund from the depositors as well as investors and lend to the borrowers in different projects and during the allocation of funds the bank should scrutinize with great thoroughness the different aspects of loan applications so that the bank's funds are not drained to unprofitable projects. The sound banking systems help safeguard depositor's interest, maintain the stability of the systems and preserve the reputation of the banking sector (Ahmed \& Dey, 2010). In case of sound system, the bank can prevent infringement of the law and corrupt practices. Presently, we live in a global village and it is natural that some of the borrowers or most of the borrowers may be engaged in trading globally. The borrowers may change their business after obtaining the loan (Abedin et al., 2013). So, it is not possible for a particular branch of a bank to monitor the post loan activities of a borrower. Bank is actually official intermediaries of money. Nobody wants that the banks are engaged in providing funds for performing out of norms because then they cannot maintain the customers' interest. Since most of the money belongs to investors and not their own, the customers desire that the money be handled ethically. Transparency and accountability of banks depend on proper accounting and reporting mainly and it contributes positively on proper functioning of banks (Kamal, and Bhuiyan, 2003; Begum et al., 2012). The financial reporting practice concept has obtained ample weight owing to expansion in company form of organization, rising competition among corporations and users' extended needs of information. Financial reporting denotes transmission of relevant information by the business entities to the concerned group like insider along with outsider users (Tewari, 2017). Financial reporting is accused in those circumstances as there are conspicuous allegation that the disclosed financial information could have saved the 
destruction to some extent, though not absolutely (Hussain, 2015a). Sound business practices and profitability of a business entity is evaluated and interpreted with financial condition as revealed in the annual reports. To communicate among different stakeholders of the business entity annual reports are the most extensive way. The company that makes full disclosure receives more attention by the investors. (Tewari, 2017). In Bangladesh the banking sector is regulated by the selected provisions of different legal frameworks like the Companies Act of 1994, the Bank Companies Act of 1991, the Securities and Exchange Rules of 1987, the Securities and Exchange Ordinance of 1969 and Bangladesh Bank Order of 1972, IAS, IFRSs and other applicable rules prescribed by the Bangladesh Bank along with the provisions of GAAP.

Financial reporting practice is regulated by the provisions of different laws and regulations and it provides information through preparing the financial statements regarding the operating results as well as the financial position of any business to the interested stakeholders to make logical decisions as per requirements (Khan et al., 2020; Neogy and Ahmed, 2015). Basically, this study has given emphasis on the application of different units of GAAP in preparing the different financial statements. To report the level of application status of the different units of GAAP for financial reporting practices by the sample banks this study has gleaned the opinions from the designated respondents in this regard. Both ANOVA and Chi Square statistical techniques have been employed to check the consistency of respondents' opinion. In this regard the null hypothesis is: $\mathrm{H}_{0}$ : There is no significant deviation among the respondents' opinions with regard to the execution status of different units of GAAP for financial reporting practices by the sample banks.

\section{Statement of the Problem}

Financial reporting that strengthens accountability and enrich knowledge regarding the financial position and cash flows of a business enterprise by way of a set of general-purpose financial statements which is useful to an extensive variety of users to make multifariousness investment, credit as well as supplementary decisions together with tax assessment (Ahmed, 2009). Stakeholders require to know the financial position of the entity as a result of its past performances to anticipate and forecast ongoing or future capacity of the business (Neogy, 2015). They depend upon the information that the concerned entity transmits to facilitate their decision making. Therefore, it is of predominant significance that the information be convenient and attributive of qualitative property (Hussain, 2015b). The Generally Accepted Accounting Principles (GAAP) in Bangladesh is based upon standards set by the ICAB, which has stated its intention to adopt international financial reporting standards (Hossain et al., 2015).

\section{Research Questions}

The researcher has pointed out the following research questions:

1. To what extent the different segments of GAAP are applied for preparing the financial statements by the banking companies in Bangladesh?

2. Is there any remarkable deviation among the respondents' opinion with regard to the application of different GAAPs for financial reporting practice of the sample banks?

\section{Research Objectives}

The main objective of this research study is to investigate the respondents' opinion regarding the application of different units of GAAP for financial reporting practice by the sample banks and the specific objectives are:

1. To analyze the collected acumen of the respondents with regard to the application of different segments of GAAP for financial reporting practice by the sample banks.

2. To examine the difference among the respondents' opinion with regard to the application of different segments of GAAP for financial reporting practice by the sample banks.

\section{Research Hypothesis}

To meet the study objectives researcher has formulated and assessed the following null hypothesis: $\mathrm{H}_{01}$ : There is no significant difference of opinions among the respondents regarding the application of different segments of GAAP for financial reporting practice by the sample banks.

\section{Research Methodology}

This study has considered only state-owned commercial banks. So, the entire state-owned commercial banks are the target population of the study. This study has considered four state-owned commercial banks as sample like Sonali Bank Limited (SBL), Agrani Bank Limited (ABL), Janata Bank Limited (JBL) and Rupali Bank Limited (RBL) using by the purposive sampling technique. This study has employed basically primary data and the required data have been collected with the use of the five points of Likert model such as strongly agree $=5$, moderately agree $=4$, slightly agree $=3$, neutral $=2$ as well as disagree $=1$ structured questionnaire from the target respondents. To meet the purpose of the study the researcher has considered a total of 150 respondents which comprise of 50 chartered accountants, 50 cost and management accountants as well as 50 academicians. To reveal the study findings this study has employed frequency analysis, different descriptive statistics, ANOVA technique as well as Chi-square test have been used to verify the developed hypotheses in null form with the use of SPSS software. 


\section{ANALYSIS AND STUDY FINDINGS}

Application of GAAP: GAAP are most influential for financial reporting practices. The accounting profession has developed a common set of rules and guidelines which are followed in accounting universally which are called Generally Accepted Accounting Principles (GAAP). Reviewing the annual reports of the sample banks it is evident that they go after the different units of GAAP to prepare the financial statements and to perceive the degree of application of various segment of GAAP in producing the financial reports by sample banks this study has collected opinions of the respondents and conducted ANOVA test as well as chi-square test through formulating the null hypothesis which is $\mathrm{H}_{0}$ : There is no material deviation among the respondents' opinion with regard to the application of the different segments of GAAP for producing and presenting the financial statements by the sample banks.

Analysis of the Perceptions about the Application of Accounting Entity Assumption as a segment of GAAP for Financial Reporting Practice: The economic entity assumption means that the financial events of the business organization must be maintained separately and distinctly from its owner as well as other business entities (Weygandt et al., 2009; Quader et al., 2010). To report the level of application of accounting entity assumption in preparing the different financial statements under the financial reporting practice by the sample banks this study has collected opinions from the respondents regarding this issue and the results are tabulated below:

Table 1: The Results of Frequency Analysis about the Application of Accounting Entity Assumption as a unit of GAAP

\begin{tabular}{|c|c|c|c|c|c|c|c|}
\hline $\begin{array}{c}\text { Values } \\
\text { of LS }\end{array}$ & Frequency & Percent & $\begin{array}{c}\text { Valid } \\
\text { Percent }\end{array}$ & $\begin{array}{c}\text { Cumulative } \\
\text { Percent }\end{array}$ & \multicolumn{3}{|c|}{ Descriptive Statistics } \\
\hline 2.00 & 1 & .7 & .7 & .7 & & & \\
\hline 3.00 & 1 & .7 & .7 & 1.3 & & & \\
\hline 4.00 & 36 & 23.8 & 24.0 & 25.3 & \multirow{2}{*}{4.727} & 0.503 & -1.967 \\
\hline 5.00 & 112 & 74.2 & 74.7 & 100.0 & & & \\
\hline Total & 150 & 99.3 & 100.0 & & & & \\
\hline
\end{tabular}

Source: Analysis of Opinion Survey Report

This evidence has presented the respondents' opinion with regard to the application of accounting entity assumption as a unit of GAAP by the sample banks for producing the financial statements shown in the annual report. The information shows that $74.7 \%$ of the respondents have fully agreed, $24.0 \%$ of the respondents moderately agreed, $0.7 \%$ of the respondents slightly agreed and $0.7 \%$ of the respondents were neutral in this regard. In addition, the mean value of response is 4.727 which mean that the respondents' opinions in this regard are greatly important. Referring to the above discussion it has been found that the majority respondents thought that the sample banks fully applied the accounting entity assumption in preparing the financial statements by the sample banks.

\section{The Formulation of Null Hypothesis}

To investigate whether there is any material deviation among the respondents opinion regarding the use of accounting entity assumption as a unit of GAAP by the sample banks this study has conducted ANOVA as well as chi-square test and developed a null hypothesis which is:

$\mathrm{H}_{0.1}$ : There is no material deviation among the respondents' opinion with regard to the application of accounting entity assumption by the sample banks for preparing the financial statements under the financial reporting practice.

Table 2: The Results of ANOVA Test

\begin{tabular}{|l|c|c|c|c|c|}
\hline & $\begin{array}{c}\text { Sum of } \\
\text { Squares }\end{array}$ & df & $\begin{array}{c}\text { Mean } \\
\text { Square }\end{array}$ & F & Sig. \\
\hline Between Groups & 2.413 & 2 & 1.207 & 5.014 & 0.008 \\
\hline Within Groups & 35.380 & 147 & 0.241 & & \\
\hline Total & 37.793 & 149 & & & \\
\hline
\end{tabular}

Source: Analysis of Opinion Survey Report

By referring to the results of ANOVA test it is evident that the value of $\mathrm{F}$ ratio is 5.014 and its value of $\mathrm{P}$ is 0.008 which is lower than 0.05 level of significance and the null hypothesis is rejected. So, it can be decided that there is material deviation among the respondents' opinion regarding the application of accounting entity assumption by the sample banks in preparing the financial statements under the financial reporting practice.

Table 3: The Results of Chi-Square Test

\begin{tabular}{|l|c|c|c|}
\hline & Value & df & $\begin{array}{c}\text { Asymp. } \\
\text { Sig. (2-sided) }\end{array}$ \\
\hline Pearson Chi-Square & 13.863 & 6 & 0.031 \\
\hline Likelihood Ratio & 14.983 & 6 & 0.020 \\
\hline Linear-by-Linear Association & 8.871 & 1 & 0.003 \\
\hline N of Valid Cases & 150 & & \\
\hline
\end{tabular}

Source: Analysis of Opinion Survey Report

By analyzing the results of Chi-square test it is apparent that the value of $\chi^{2}$ is 13.863 and the $P$ value is significant at $5 \%$ level which means the null hypothesis is rejected and it designates that there is material deviation among the respondents' opinion relating to the application of accounting entity assumption by the sample banks in preparing the financial statements under the financial reporting practice.

Analysis of the Perceptions about the Application of Going Concern Assumption as a Part of GAAP for Financial Reporting Practice: The accounting unit is considered to have a long life to carry out its commitments, obligations, and objectives, and so on than that of any asset which it now owns. For accounting purposes, the assumption always goes in favor of considering the business to operate for an indefinitely long period of time (Khan, 1995). To know the level of application of going concern assumption in maintaining the different financial statements under the financial 
reporting practice this study has conducted opinions survey in this regard and the analysis of the opinions are given below:

Table 4: The Results of Frequency Analysis about the Application of Going Concern Assumption as a unit of GAAP

\begin{tabular}{|c|c|c|c|c|c|c|c|}
\hline Values & Frequency & Percent & \multirow{2}{*}{$\begin{array}{c}\text { Valid } \\
\text { of }\end{array}$} & & & Cumulative & \multicolumn{3}{|c|}{ Descriptive Statistics } \\
\cline { 4 - 6 } & & & Percent & Percent & Mean & SD & Skewness \\
\hline 3.00 & 8 & 5.3 & 5.3 & 5.3 & & & \\
\hline 4.00 & 41 & 27.2 & 27.3 & 32.7 & \multirow{3}{*}{4.620} & 0.587 & -1.286 \\
\hline 5.00 & 101 & 66.9 & 67.3 & 100.0 & & & \\
\hline Total & 150 & 99.3 & 100.0 & & & & \\
\hline
\end{tabular}

Source: Analysis of Opinion Survey Report

This aforesaid information reveals the respondents' opinion with respect to the application of going concern assumption by the sample banks in preparing the financial statements. It is apparent from the above evidence that $67.3 \%$ of the respondents have fully agreed, $27.3 \%$ of the responders have moderately agreed and $5.3 \%$ of the responders have slightly agreed in this matter. The above evidence also reports that the mean value of the respondents' responses is 4.620 that supports the opinions of the respondents in this point are momentous. Based on the aforesaid deliberation it is found that most of the respondents thought that the sample banks have fully applied the going concern assumption for maintaining the financial statements.

\section{The Formulation of Null Hypothesis}

To assess whether there is any material deviation among the respondents' opinion with respect to the execution of going concern assumption for producing the financial statements under the financial reporting practice this study has conducted ANOVA as well as chi-square test with the help of a null hypothesis which is:

H01.2: There is no significant difference among the respondents' opinion regarding the application of going concern assumption for preparing the financial statements by the sample banks.

Table 5: The Results of ANOVA Test

\begin{tabular}{|l|c|c|c|c|c|}
\hline & $\begin{array}{c}\text { Sum of } \\
\text { Squares }\end{array}$ & df & $\begin{array}{c}\text { Mean } \\
\text { Square }\end{array}$ & F & Sig. \\
\hline Between Groups & 4.680 & 2 & 2.340 & 7.372 & 0.001 \\
\hline Within Groups & 46.660 & 147 & 0.317 & & \\
\hline Total & 51.340 & 149 & & & \\
\hline
\end{tabular}

Source: Analysis of Opinion Survey Report

By considering the results of ANOVA test it is observable that the value of $F$ ratio is 7.372 and the $p$ value is 0.001 which means the value is lower than 0.05 level of significance. So, the null hypothesis is rejected and it is apparent that there is material deviation among the respondents' opinion in respect of the application of going concern assumption for producing the different financial statements under the financial reporting practice by the sample banks.
Table 6: The Results of Chi-Square Test

\begin{tabular}{|l|c|c|c|}
\hline & Value & df & $\begin{array}{c}\text { Asymp. Sig. } \\
\text { (2-sided) }\end{array}$ \\
\hline Pearson Chi-Square & 14.611 & 4 & 0.006 \\
\hline Likelihood Ratio & 17.383 & 4 & 0.002 \\
\hline Linear-by-Linear Association & 6.530 & 1 & 0.011 \\
\hline N of Valid Cases & 150 & & \\
\hline
\end{tabular}

(ource: Analysis of Opinion Survey Report

The results of chi-square test delineate that the value of $\chi^{2}$ is 14.611 and its $\mathrm{P}$ value is significant at 5\% level and the null hypothesis is rejected. It is logical to say that there is material deviation among the respondents' opinion in respect of the application of going concern assumption for preparing the financial statements by the sample banks.

Analysis of the Perceptions about the Application of Stable Monetary Unit Assumption as a Part of GAAP for Financial Reporting Practice: The monetary unit assumption assumes that the economic entities record the transactions and data in the accounting records which can be measured in terms of money. This assumption believes in stable monetary unit. The monetary unit assumption is important to employ the cost principle (Weygandt et al., 2009). To know the level of application of monetary measurement assumption for preparing the financial statements by the sample banks under the financial reporting practice this study has conducted opinions survey in this regard and the analysis of the opinions are given below:

Table 7: The Results of Frequency Analysis about the Application of Stable Monetary Unit Assumption as a Unit of GAAP

\begin{tabular}{|c|c|c|c|c|c|c|c|}
\hline \multirow{2}{*}{$\begin{array}{c}\text { Values } \\
\text { of LS }\end{array}$} & \multirow[t]{2}{*}{ Frequency } & \multirow[t]{2}{*}{ Percent } & \multirow{2}{*}{\begin{tabular}{|c|} 
Valid \\
Percent \\
\end{tabular}} & \multirow{2}{*}{$\begin{array}{c}\text { Cumulative } \\
\text { Percent }\end{array}$} & \multicolumn{3}{|c|}{ Descriptive Statistics } \\
\hline & & & & & Mean & SD & Skewness \\
\hline 1.00 & 1 & .7 & .7 & .7 & \multirow{6}{*}{4.54} & \multirow{6}{*}{0.672} & \multirow{6}{*}{-1.964} \\
\hline 2.00 & 2 & 1.3 & 1.3 & 2.0 & & & \\
\hline 3.00 & 3 & 2.0 & 2.0 & 4.0 & & & \\
\hline 4.00 & 53 & 35.1 & 35.3 & 39.3 & & & \\
\hline 5.00 & 91 & 60.3 & 60.7 & 100.0 & & & \\
\hline Total & 150 & 99.3 & 100.0 & & & & \\
\hline
\end{tabular}

Source: Analysis of Opinion Survey Report

This above Table has reported that the respondents' opinion with reference to the application of stable monetary unit assumption by the sample banks for producing the financial statements. From the previous evidence it is apparent that $60.7 \%$ of the respondents have fully agreed but $0.7 \%$ of the respondents disagreed in this point. Moreover $35.3 \%$ have moderately agreed, $2.0 \%$ of the respondents have slightly agreed and $1.3 \%$ of the respondents were neutral in this regard. The mean value of the respondents' opinions is 4.54 which means that the opinions of the respondents in this regard are of paramount importance. It has been obtained from the above evidence that the majority respondents thought that the sample banks have applied the monetary measurement assumption for producing the different financial statements under the financial reporting practice. 


\section{The Formulation of Null Hypothesis}

To examine whether there is any material deviation among the respondents' opinion with reference to the application of monetary measurement assumption this study has conducted ANOVA as well as Chi-square test with the use of a null hypothesis which is:

H01.3: There is no material deviation among the respondents' opinion regarding the application of monetary measurement assumption in preparing the financial statements by the sample banks.

Table 8: The Results of ANOVA Test

\begin{tabular}{|l|c|c|c|c|c|}
\hline & $\begin{array}{c}\text { Sum of } \\
\text { Squares }\end{array}$ & df & $\begin{array}{c}\text { Mean } \\
\text { Square }\end{array}$ & F & Sig. \\
\hline Between Groups & 3.360 & 2 & 1.680 & 3.865 & 0.023 \\
\hline Within Groups & 63.900 & 147 & 0.435 & & \\
\hline Total & 67.260 & 149 & & & \\
\hline
\end{tabular}

Source: Analysis of Opinion Survey Report

The results of ANOVA test exhibit that the value of $\mathrm{F}$ ratio is 3.865 and the $P$ value is significant at $5 \%$ level. So, that the null hypothesis is rejected which indicates that there is material deviation among the respondents' opinion regarding the application of monetary measurement assumption for producing the financial statements by the sample banks.

Table 9: The Results of Chi-Square Test

\begin{tabular}{|l|c|c|c|}
\hline & Value & df & $\begin{array}{c}\text { Asymp. Sig. } \\
\text { (2-sided) }\end{array}$ \\
\hline Pearson Chi-Square & 13.264 & 8 & 0.103 \\
\hline Likelihood Ratio & 14.655 & 8 & 0.066 \\
\hline Linear-by-Linear Association & 0.798 & 1 & 0.372 \\
\hline N of Valid Cases & 150 & & \\
\hline
\end{tabular}

Source: Analysis of Opinion Survey Report

By analyzing the results of Chi-square test it is clear that the value of $\chi 2$ is 13.264 and the significant level is 0.103 and the null hypothesis is accepted which indicates that there is no material deviation among the respondent' opinion in regard to the application of monetary measurement assumption for producing the different financial statements under the financial reporting practice by the sample banks.

Analysis of the Perceptions about the Application of Time Period Assumption as a Part of GAAP for Financial Reporting Practice: Timeliness is a character which makes the information important. To take important decisions and appropriate actions, the decision makers must obtain necessary information periodically. To provide latest and relevant financial information accounting systems produce statements at regular intervals. The time period assumption holds that an entity's tasks can be divided into definite and equal time periods such as a month, a quarter, or a year. Generally, most of the entities use a year as their accounting period (Ahmed, 2020; Donepudi et al., 2020; Ahmed, 2021). To know the application of time period assumption to construct the various financial statements by the sample banks under the financial reporting practice this study has conducted opinions survey in this regard and the analysis of the opinions are given below:

Table 10: The Results of Frequency Analysis about the Application of Time Period Assumption as a Unit of GAAP

\begin{tabular}{|c|c|c|c|c|c|c|c|}
\hline \multirow{2}{*}{\begin{tabular}{|c|} 
Values \\
of LS
\end{tabular}} & \multirow[t]{2}{*}{ Frequency } & \multirow[t]{2}{*}{ Percent } & \multirow{2}{*}{$\begin{array}{c}\text { Valid } \\
\text { Percent }\end{array}$} & \multirow{2}{*}{$\begin{array}{c}\text { Cumulative } \\
\text { Percent }\end{array}$} & \multicolumn{3}{|c|}{ Descriptive Statistics } \\
\hline & & & & & Mean & $\mathrm{SD}$ & Skewness \\
\hline 3.00 & 4 & 2.6 & 2.7 & 2.7 & \multirow{4}{*}{4.673} & \multirow{4}{*}{0.525} & \multirow{4}{*}{-1.301} \\
\hline 4.00 & 41 & 27.2 & 27.3 & 30.0 & & & \\
\hline 5.00 & 105 & 69.5 & 70.0 & 100.0 & & & \\
\hline Total & 150 & 99.3 & 100.0 & & & & \\
\hline
\end{tabular}

Source: Analysis of Opinion Survey Report

This information presents the opinion of the responders concerning the application of time period assumption for constructing the different financial statements by the sample banks and it reports that $70.0 \%$ of the respondents have fully agreed, $27.3 \%$ of the responders have moderately agreed and $2.7 \%$ of the responders have slightly agreed in this regard. The aforesaid discussion reports that the mean value of the responses is 4.673 that indicate the opinions of the respondents are suggestive. Referring to the previous evidence it is found that the majority respondents thought that the sample banks fully apply the time period assumption for preparing the different financial statements under the financial reporting practice by the sample banks.

\section{The Formulation of Null Hypothesis}

To investigate whether there is any material deviation among the respondents' opinion in regard to the application of time period assumption for constructing the different financial statements under the financial reporting practice this study has conducted ANOVA as well as Chi-square test through developing a null hypothesis which is:

H01.4. There is no material deviation among the respondents' opinion respecting the application of time period assumption for constructing the financial statements by the sample banks.

Table 11: The Results of ANOVA Test

\begin{tabular}{|l|c|c|c|c|c|}
\hline & $\begin{array}{c}\text { Sum of } \\
\text { Squares }\end{array}$ & df & $\begin{array}{c}\text { Mean } \\
\text { Square }\end{array}$ & F & Sig. \\
\hline Between Groups & 2.253 & 2 & 1.127 & 4.275 & 0.016 \\
\hline Within Groups & 38.740 & 147 & 0.264 & & \\
\hline Total & 40.993 & 149 & & & \\
\hline
\end{tabular}

Source: Analysis of Opinion Survey Report

From the Table of ANOVA test it is apparent that the value of $\mathrm{F}$ ratio is 4.275 and the $\mathrm{P}$ value is 0.016 , significant at $5 \%$ level which means that the null hypothesis is rejected and it indicates that there is material deviation of opinion among the responders regarding the application of time period assumption for preparing the different financial statements under the financial reporting practice by the sample banks. 
Table 12: The Results of Chi-Square Test

\begin{tabular}{|l|c|c|c|}
\hline & Value & df & $\begin{array}{c}\text { Asymp. Sig. } \\
\text { (2-sided) }\end{array}$ \\
\hline Pearson Chi-Square & 12.294 & 4 & 0.015 \\
\hline Likelihood Ratio & 12.261 & 4 & 0.016 \\
\hline Linear-by-Linear Association & 8.178 & 1 & 0.004 \\
\hline N of Valid Cases & 150 & & \\
\hline
\end{tabular}

Source: Analysis of Opinion Survey Report

By analyzing the results of Chi-square test it is evident that the value of $\chi 2$ is 12.294 and the $P$ value is significant at $5 \%$ level which means the null hypothesis is rejected. So, there is material deviation among the respondent' opinion regarding the application of time period assumption for constructing the different financial statements under the financial reporting practice by the sample banks for the interested stakeholder to make sound decisions.

\section{Test of Reliability}

This study has employed Chronbach's Alpha technique to know the reliability of respondents' opinions regarding the different segments of GAAP in producing the different financial statement by the sample banks under the financial reporting practice and the consequence in this regard are given in the following Table:

Table 13: The results of Cronbach Alpha test

\begin{tabular}{|c|c|c|c|c|}
\hline Items & Mean & Variance & SD & Alpha Value \\
\hline 04 & 18.5600 & 4.463 & 2.11254 & 0.938 \\
\hline
\end{tabular}

Source: Analysis of Opinion Survey Report

The aforesaid information has reported that the results of Cronbach Alpha test about the respondents' opinion in respect of the application of different segments of GAAP in producing the different financial statements under the financial reporting practice by the sample banks and referring to this it is evident that the value of Alpha is 0.938 which means that the respondents' opinions in this point are reliable.

\section{CONCLUSION}

Financial reporting practices are regulated by the provisions of different laws and regulations as well as the requirements of the different units of Generally Accepted Accounting Principles (GAAP) and disseminate information by way of the financial reporting contained in the annual reports that is useful to make logical decisions as per requirements of the interested users. The principal objective of this study is to assess the extent of application status of the different components of GAAP in formulating the different financial statements under the reporting practices by the sample banks in the light of respondents' opinions. The result of opinion survey shows the opinion of the respondents regarding the use of GAAP in preparing the financial statements by the sample banks. With a view to know whether there is any material deviation among the respondents' opinions in respect of the application status of the different segments of GAAP in financial reporting practices by the sample banks this study has employed the ANOVA as well as Chi-Square tests. The evidence reveals that there is material deviation in the opinion of respondents in case of the application of accounting entity assumption, going concern assumption as well as time period assumption and there is no material deviation among the respondents' opinion respecting the application status of monetary measurement assumption as a segment of GAAP in producing the different financial statements under the reporting practices by the sample banks. The expectation of stakeholders to get quality information in case of making decision can be possible if the different financial reports are prepared in accordance with of the provisions of the different units of Generally Accepted Accounting Principles (GAAP).

\section{REFERENCES}

Abedin, M. M., Ahmed, A. A. A. and Neogy, T. K. (2013). Mechanism of Accountability and Auditing: Public Sector Scenarios of Bangladesh. Journal of Business Studies, 4, 131-148.

Ahmed, A. A. A. (2020). Corporate attributes and disclosure of accounting information: Evidence from the big five banks of China. J Public Affairs. e2244. https://doi.org/10.1002/pa.2244

Ahmed, A. A. A. (2021). Perception of the audience of interests on the qualitative characteristics of financial reporting. International Journal of Intellectual Property Management. https://doi.org/10.1504/IJIPM.2021.10038267

Ahmed, A. A. A., \& Dey, M. M. (2010). Accounting Disclosure Scenario: An Empirical Study of the Banking Sector of Bangladesh. Accounting and Management Information Systems, 9(4), 581-602. https://doi.org/10.5281/zenodo.4008276

Ahmed, A. A. A., (2009). Compliance of Financial Disclosure in Corporate Annual Reports of Banking Sector in Bangladesh. Unpublished Ph. D Thesis, Department of Accounting and Information Systems, University of Rajshahi, Bangladesh.

Begum, R., Ahmed, A. A. A., Neogy, T. K. (2012). Management Decisions and Univariate Analysis: Effects on Corporate Governance in Bangladesh. Journal of Business Studies, Volume 3, 87-115.

Donepudi, P. K., Banu, M. H., Khan, W., Neogy, T. K., Asadullah, ABM., \& Ahmed, A. A. A. (2020). Artificial Intelligence and Machine Learning in Treasury Management: A Systematic Literature Review. International Journal of Management, 11(11), $13-22$. https://doi.org/10.5281/zenodo.4247297 
Hossain, M. S., Hasan, M. S., \& Safiuddin, M. (2015). Adoption of International Financial Reporting Standards in Bangladesh: Benefits and Challenges. Research Journal of Finance and Accounting, 6(13), 116-125.

Hussain, M. J., (2015a). Financial Reporting Regulations Go Global-A Cerebral Review. The Bangladesh Accountant, October - December.

Hussain, T., (2015b). Financial Reporting in Bangladesh. The Bangladesh Accountant, October - December.

Kamal, Y. and Bhuiyan, N. U. (2003). Standardization of Accounting and Financial Reporting Practices in the Banking Sector in Bangladesh: An Evaluation of the Implementation of IAS 30 by the Banks in the Private Sector. Dhaka University Journal of Business Studies, 24(2), 25-37. Available at SSRN: https://ssrn.com/abstract=1944505

Khan, M. M., (1995). Advanced Accounting. Ideal Library, Dhaka, Bangladesh, Volume 1

Khan, W., Ahmed, A. A. A., Hossain, M. S., Neogy, T. K. (2020). The Interactive Approach to Working Capital Knowledge: Survey Evidence. International Journal of Nonlinear Analysis and
Applications, 11(Special Issue), 379-393. https://doi.org/10.22075/ijnaa.2020.4631

Neogy, T. K and Ahmed, A. A. A., (2015). The Extent of Disclosure of Different Components of Disclosure Index: A Study on Commercial Banks in Bangladesh. Global Disclosure of Economics and Business, 4(2).

Neogy, T. K., (2015). Evaluation of the Legal Framework and Accounting Standards: A Study on Mobile Telecommunication Companies in Bangladesh. ABC Journal of Advanced Research, 4(1).

Quader, M. T., Neogy, T. K., Ahmed, A. A. A. (2010). Econometric Growth Rates Analysis of Basic Bank Limited in Bangladesh: An Evaluation. Development Compilation, 4(1), 48-60.

Tewari, M., (2017). Financial Reporting Practices in Commercial Banks in India - A Comparative Study. Proceedings of $49^{\text {th }}$ IRF International Conference, $16^{\text {th }}$ April, Chennai, India.

Weygandt, J. J., Kimmel, P. D. and Kieso, D. E. (2009). Accounting Principles, 9th ed., John Wiley \& Sons Inc., New Jersey. 


\section{How to Cite This Article}

Banu, M. H., Sayaduzzaman, M., \& Sil, S. C. (2021). Evaluation the Application Status of GAAP in Financial Reporting Practice: In Case of Banking Sector in Bangladesh. Asian Business Review, 11(2), 67-74. https://doi.org/10.18034/abr.v11i2.577 